Journal Universitas Muhammadiyah Gresik Engineering, Social Science, and Health International Conference (UMGESHIC)

UMGCINMATIC : $1^{\text {st }}$ Rethinking Education during Covid-19 Era: Challange and Innovation

\title{
THE USE OF CONSTRUCTIONISM TO DEVELOP STUDENTS' COMMUNICATION SKILLS THROUGH A SHARE LEARNING PROCESS
}

\author{
Warapon Yostasarn $^{1}$, Shofiyatul Najah ${ }^{2}$, Wanida Simpol ${ }^{3}$ \\ Warapon Yostasarn , Bannonsawan School, Erawan, Loei 42220, Thailand \\ Shofiyatul Najah, Universitas Muhammadiyah Gresik, East Java 61121, Indonesia \\ Wanida Simpol, Loei Primary Educational Service Area Office 2, Wangsaphung, Loei \\ 42130
}

\begin{abstract}
The objectives of this study were (1) to develop English learning through a SHARE learning process based on Constructionism theory to develop achievement with an efficiency of 75/75, (2) to compare the students' achievement between before learning and after learning, and (3) to compare the students' attitude towards English learning through a SHARE learning process between before learning and after learning. For the research tools, the researcher used 10 lesson plans followed a SHARE learning process of Constructionism theory, communication assessments for learning English for communication, and the evaluation of students' attitude towards English learning a SHARE learning process based on Constructionism theory. The results showed that (1) the development of English learning through a SHARE learning process had an efficiency of 82.15/83.21, (2) the students' communication development after using English learning through a SHARE learning process based on Constructionism theory was higher than before statistically at the .05 level of significance, and (3) students' attitude toward English learning was very satisfied.
\end{abstract}

Keyword: communication skills, communicative language approach, Constructionism

\section{Suggested Citation:}

Yostasarn, W. (2021). The use of Constructionism to develop students' communication skills through a SHARE learning process. Proceeding of Universitas Muhammadiyah Gresik Social Humanity International Conference (UMGCINMATIC). 0(0), 000-000. 


\section{INTRODUCTION}

Foreign languages are very important and necessary in everyday life. because it is an important tool for communication English is a skill subject. to make teaching and learning effective and the effectiveness Must rely on the main component is the learner is a skill trainer. Teachers develop learners to develop skills. The main factors used to develop are various teaching and learning processes. (Ministry of Education, 2010, p.190)

Constructionism theory is based on the theory Constructionism that focuses on the process of developing learners' learning is learning by practice or creating things (Papert, 1999). Create a diverse and sufficient body of knowledge. to be a medium. Helping to think helps to make things that are difficult to learn become concrete. Help learners to build their own body of knowledge. Learners will understand things deeply and have the ability to learn very well (Papert, 1993).

Guidelines for innovation in learning management according to the concept of learning theory for creative intelligence or the theory of self-knowledge (Constructionism) by using the SHARE process with the following thinking guidelines emphasize the importance of the learner's learning process. and the importance of prior knowledge and give students the opportunity to express their knowledge by themselves, and able to create knowledge on their own Learners will go out and observe what they want to know. There are 5 steps of SHARE Process to create the activities in the class, S : Stimulus, $\mathrm{H}$ : Hypothesis, A : Action, R : Reflection and E : Evaluation.

\section{METHOD}

The use of Constructionism to develop students' communication skills through a SHARE learning process. The researcher proceeded with the following steps:

1. Target group

2. Research tools

3. Creation and quality of tools

4. Data collection

5. Data manipulation and data analysis

6. Data analysis

The researcher proceeded according to the research framework by studying the problem conditions and background information. Learning management practice related to the development of students' English communication skills. Study course Concepts and theories about Communicative Language Teaching, Activity-based learning, Cooperative Learning, Creativity Based Learning, and Team-Based Learning using the collected data to design the learning activities process and present them to research advisors and experts, to check the quality of the learning process as to the validity, comprehensiveness, and feasibility to improve by applying the concept of the Constructionism inverted as well as the students' basic needs and abilities in a learning context. To connect with the framework of the activities of learning English subjects in this research for students to be successful their English communication by steps as follows.

\subsection{Participants}

In this research, the target group consisted of 33 students in Garde 8 students at Bannonsawan School, Erawan District, Loei Province, Loei Primary Educational Service Area Office 2, totaling 33 students in the first semester of the academic year 2021. Purposive Sampling 


\section{Research scope}

The researcher has defined the scope of research as follows.

1. The scope of content used in the research is the content according to the core curriculum of basic education, B.E. 2551 (2008), the subject group for learning foreign languages (English), grade 8, semester 1 of the academic year 2021 to prepare a plan. A total of 6 learning plans were organized for 12 hours in total.

Unit 1: Welcome to my hometown.

Plan 1 My hometown, 2 hours

Plan 2 The idol in my town, 2 hours

Plan 3 I love my school, 2 hours

Plan 4 Let's go to the temple, 2 hours

Plan 5 Local market, 2 hours

Plan 6 Make money work happy, 2 hours

2. Scope of the target group

The scope of the research target group consists of the target groups as follows: Grade 8 students at Bannonsawan School, Erawan District, Loei Province, under the Office of Elementary Education Service Area 2, in the first semester of the academic year 2021, The use of Constructionism to develop student's communication skills through a SHARE learning process. observe the behavior of learning management in one English subject classroom of 33 students, which were obtained by -(Purposive Sampling)

3. Scope of learning model the use of Constructionism to develop student's communication skills through a SHARE learning process

The researcher will use the information that appears from the study to analyze. synthesized in the beginning Let's design learning management to be detailed in the process of learning management in English. Grade 8 for learning management for learners to achieve the ability to practice English communication and to develop students' English Skills.

4. Time boundaries

The researcher will spend time researching in the first semester of the academic year 2021 from June 2021 to October 2021 by organizing learning activities by foreign language learning subjects. by applying the concept of using of Constructionism to develop student's communication skills through a SHARE learning process by selecting content from the scope 1 unit, 6 contents, 12 hours.

5. Variables studied

5.1 Primary variables or independent variables 6 plans for learning management using the concept of constructionism through a SHARE learning process.

5.2 English language learning achievement of Grade 8 students by using the concept of constructionism through a SHARE learning process.

5.3 Students' satisfaction in English learning using the concept of constructionism through a SHARE learning process.

\subsection{Measures}

Innovative design to develop learning management processes by using the concept of constructionism through a SHARE learning process by studying documents and research on learning activities by applying the concept of constructionism through a SHARE learning process. It was found that the content and components of the learning activities that covered the important issues in the learning activities should consist of learning activities format 
Characteristics of learning activities. The process of organizing learning activities to determine the steps in the development of learning activities.

The research tools were:

1. Constructionism through a SHARE learning process lesson plans for Grade 8 students : 6 lesson plans, 12 hours.

2. Multiple choice test to investigate the students' English learning achieving before and after learning by using the designed lesson plans, contained 30 items, 30 points (1 point each).

3. Student Learning Satisfaction Questionnaire towards learning management using of Constructionism to develop student's communication skills through a SHARE learning process.

\subsection{Procedure and design}

\section{Before teaching (outside the classroom)}

Make a plan. Teachers design lesson plans. set teaching objectives Selection of teaching media and supplementary activities that are appropriate for the learner's age, classroom, and school context.

Procedure and design were one group pretest and posttest design.

Analyze student's problems, Reviews Literature, and other content, and create an English Lesson plan. The lesson plans were constructed through 5 stages as follows.

\section{In the classroom}

Teacher teach in the class by using SHARE learning process lesson plans. There are 5 steps of SHARE Process to create the activities in the class.

Step $1 \mathrm{~S}$ : Stimulus. The teacher use activities Methods or teaching materials that stimulate students' interest in learning by linking with the same experience Teachers may use games, music, or online media. from various channels To stimulate the interest of students before entering the new content.

Step $2 \mathrm{H}$ : Hypothesis. The teacher uses a variety of questions to enable students to create creative ideas. have predictions or assumptions or the expected outcome Teacher questions can take many forms, such as Asking by using WH questions or they can be asked using pictures, asking with a game, or asking with open-ended questions.

Step $3 \mathrm{~A}$ : Action. The students have participate to do the activity to practice 4 skills. Exchange to encourage interaction between teachers. Teachers give children the opportunity to discuss, exchange, and ask questions based on the content that has been studied to develop communication. students have practiced self-learning in groups or individually The activities that teachers use to teach will be in a variety of forms, with techniques and learning methods. in finding knowledge, such as matching, talking Group discussion, solo use of music, and games.

Step $4 \mathrm{R}$ : Reflection. Students have done their work, work, projects, and have presented their own work or work to their peers in class, outside the class, and the public, which is the current situation. Teachers and students can reflect on their work online.

Step 5 E : Evaluation. Teachers assess learning on what learners have learned. by evaluating communication skills with listening, speaking, reading, and writing skills assessment form, satisfaction questionnaire. Friends, teachers or parents participate in the evaluation and praise the work so that learners learn to listen to other people's opinions. Know how to improve your work. 


\section{After teaching}

Teachers review teaching lesson plans, summarize, measurement and evaluate students' assignments. It also measures and evaluates teacher teaching. Teachers give feedback to the student to encourage and supplement challenging activities to enable students to use higher skills and more practice to a higher level.

\subsection{Data analysis}

1. Part 1 : The evaluation results of using lesson plan of Constructionism to develop student's communication skills through a SHARE learning process for Grade 8 students.

2. Part 2: The results of the review of the effectiveness of using of Constructionism to develop student's communication skills through a SHARE learning process lesson plans for Grade 8 students with an efficiency of $75 / 75$.

3. Part 3: The results of comparing the students' achievement between before learning and after learning by using Constructionism to develop student's communication skills through a SHARE learning process higher than before statistically at the .05 level of significance.

4. Part 4: The results of study students' satisfaction towards English learning through a SHARE learning process between before learning and after learning.

\section{Results}

1. Part 1 : The evaluation results of using lesson plan of Constructionism to develop student's communication skills through a SHARE learning process for Grade 8 students.

Table1. Plan evaluation results of learning management plans by using lesson plan of Constructionism to develop student's communication skills through a SHARE learning process by 3 experts assessing the quality and suitability of the plan. and the results are shown in Table 1.

\begin{tabular}{c|c|c|lc}
\hline \hline Lesson Plan & $\begin{array}{c}\text { Total average } \\
(\overline{\mathrm{x}})\end{array}$ & $\begin{array}{c}\text { Standard } \\
\text { Deviation (S.D) }\end{array}$ & \multicolumn{2}{|c}{ Interpret results } \\
\hline 1 & 4.30 & 0.55 & $\begin{array}{l}\text { Very good quality and } \\
\text { suitable }\end{array}$ \\
\hline 2 & 4.00 & 1.00 & $\begin{array}{l}\text { Very good quality and } \\
\text { suitable }\end{array}$ \\
\hline 3 & 4.40 & 0.60 & $\begin{array}{l}\text { Very good quality and } \\
\text { suitable }\end{array}$ \\
\hline 4 & 4.20 & 0.45 & $\begin{array}{l}\text { Very good quality and } \\
\text { suitable }\end{array}$ \\
\hline 5 & 4.30 & 1.00 & $\begin{array}{l}\text { Very good quality and } \\
\text { suitable }\end{array}$ \\
\hline 6 & 4.20 & 1.00 & $\begin{array}{l}\text { Very good quality and } \\
\text { suitable }\end{array}$ \\
\hline Overall & 4.23 & 1.00 & $\begin{array}{l}\text { Very good quality and } \\
\text { suitable }\end{array}$ \\
\hline
\end{tabular}

From Table 1, it was found that the assessment results of the learning management plan by using lesson plan of Constructionism to develop student's communication skills through a 
SHARE learning process by 3 experts assessing the quality and suitability of the plan. and the results are shown in Table 1, which were conducted by experts. The mean per plan ranged from $3.6-4.4$ and the overall average was 4.12 and compared with the quality and suitability criteria. According to the preliminary quality level conditions, it was found that the learning management plan applied the concept of using of Constructionism to develop student's communication skills through a SHARE learning process, the quality and appropriateness of each plan are at the highest level. and overall assessment results All plans are at a high level $(\overline{\mathrm{x}}=4.12$, S.D. $=1.00)$.

Part 2: The results of the review of the effectiveness of using of Constructionism to develop student's communication skills through a SHARE learning process lesson plans for Grade 8 students had an efficiency of 84.50/84.65

The researcher examined the effectiveness of the learning management plan. It was calculated from the scores of assessment of learning behavior during class, assessment of worksheets, and pre-and post-tests. The results are shown in the following table.

Table 2. The Results of the review of the efficiency of using of Constructionism to develop student's communication skills through a SHARE learning process lesson plans for Grade 8 students

\begin{tabular}{|c|c|c|c|c|c|c|c|c|c|}
\hline \multirow[b]{2}{*}{ Students } & \multicolumn{6}{|c|}{ Between learning Exercise score } & \multirow{2}{*}{$\begin{array}{c}\text { Total } \\
\text { score } \\
\left(E_{1}\right) \\
70\end{array}$} & \multirow{2}{*}{$\begin{array}{c}\text { Pre-test score } \\
30\end{array}$} & \multirow{2}{*}{$\begin{array}{c}\text { Post-test score } \\
\left(\mathrm{E}_{2}\right) \\
30\end{array}$} \\
\hline & $\begin{array}{c}\text { topic } \\
1 \\
10\end{array}$ & $\begin{array}{c}\text { topic } \\
2 \\
10\end{array}$ & $\begin{array}{c}\text { topic } \\
3 \\
10\end{array}$ & $\begin{array}{c}\text { topic } \\
4 \\
10\end{array}$ & $\begin{array}{l}\text { topic } \\
5 \\
10\end{array}$ & $\begin{array}{c}\text { topic } \\
6 \\
20\end{array}$ & & & \\
\hline 1 & 9 & 8 & 9 & 7 & 8 & 14 & 55 & 23 & 25 \\
\hline 2 & 8 & 7 & 8 & 8 & 9 & 15 & 55 & 21 & 24 \\
\hline 3 & 10 & 6 & 10 & 8 & 8 & 18 & 60 & 20 & 26 \\
\hline 4 & 8 & 9 & 9 & 7 & 9 & 17 & 59 & 19 & 25 \\
\hline 5 & 8 & 9 & 8 & 9 & 8 & 18 & 60 & 21 & 25 \\
\hline 6 & 9 & 6 & 9 & 7 & 9 & 15 & 55 & 20 & 23 \\
\hline 7 & 9 & 8 & 7 & 9 & 8 & 17 & 58 & 20 & 25 \\
\hline 8 & 9 & 7 & 9 & 9 & 8 & 18 & 60 & 23 & 26 \\
\hline 9 & 8 & 8 & 7 & 7 & 8 & 15 & 53 & 26 & 27 \\
\hline 10 & 9 & 6 & 9 & 6 & 8 & 16 & 54 & 25 & 27 \\
\hline 11 & 9 & 9 & 7 & 7 & 9 & 17 & 58 & 21 & 26 \\
\hline 12 & 10 & 6 & 9 & 8 & 9 & 18 & 60 & 21 & 25 \\
\hline 13 & 9 & 9 & 7 & 7 & 9 & 15 & 56 & 23 & 26 \\
\hline 14 & 10 & 9 & 9 & 6 & 9 & 16 & 59 & 22 & 26 \\
\hline 15 & 8 & 8 & 8 & 6 & 8 & 15 & 53 & 19 & 23 \\
\hline 16 & 8 & 9 & 9 & 8 & 8 & 16 & 58 & 17 & 25 \\
\hline 17 & 8 & 9 & 7 & 7 & 8 & 17 & 56 & 20 & 26 \\
\hline 18 & 8 & 9 & 10 & 7 & 10 & 15 & 59 & 20 & 25 \\
\hline 19 & 9 & 9 & 7 & 9 & 10 & 18 & 62 & 19 & 27 \\
\hline 20 & 9 & 10 & 9 & 7 & 8 & 15 & 58 & 20 & 27 \\
\hline 21 & 8 & 9 & 6 & 8 & 9 & 16 & 56 & 20 & 28 \\
\hline 22 & 9 & 9 & 8 & 7 & 10 & 17 & 60 & 22 & 25 \\
\hline 23 & 9 & 10 & 7 & 9 & 8 & 15 & 58 & 23 & 27 \\
\hline
\end{tabular}




\begin{tabular}{|c|c|c|c|c|c|c|c|c|c|}
24 & 9 & 9 & 8 & 7 & 8 & 16 & 57 & 24 & 28 \\
\hline 25 & 8 & 9 & 6 & 10 & 9 & 17 & 59 & 25 & 26 \\
\hline 26 & 6 & 9 & 8 & 7 & 10 & 18 & 58 & 20 & 21 \\
\hline 27 & 7 & 9 & 7 & 9 & 9 & 14 & 55 & 22 & 24 \\
\hline 28 & 5 & 9 & 8 & 8 & 9 & 16 & 55 & 22 & 24 \\
\hline 29 & 7 & 9 & 8 & 8 & 9 & 16 & 57 & 22 & 24 \\
\hline 30 & 8 & 9 & 8 & 8 & 8 & 16 & 57 & 20 & 29 \\
\hline 31 & 6 & 9 & 8 & 9 & 8 & 16 & 56 & 22 & 23 \\
\hline 32 & 6 & 9 & 8 & 8 & 10 & 10 & 51 & 21 & 26 \\
\hline 33 & 8 & 9 & 8 & 6 & 8 & 10 & 49 & 23 & 24 \\
\hline total & 271 & 279 & 265 & 253 & 286 & 522 & 1876 & 706 & 838 \\
\hline $\mathrm{x}$ & 8.21 & 8.45 & 8.03 & 7.67 & 8.67 & 15.82 & 56.85 & 21.39 & 25.39 \\
\hline Percent & 12.21 & 12.57 & 11.94 & 11.40 & 12.88 & 23.51 & 84.50 & 31.80 & 84.65 \\
\hline
\end{tabular}

From Table 2, the results of the review of the efficiency had the process efficiency value (E1) of 84.50, the efficiency of the result (E2) was 84.65. The efficiency (E1/E2) was $84.50 / 84.65$, higher than the set threshold of $75 / 75$.

Part 3: The results of comparing the students' achievement between before learning and after learning by using Constructionism to develop student's communication skills through a SHARE learning process higher than before statistically at the .05 level of significance. The results are shown in the following table.

Table 3, The results of comparing the students' achievement between before learning and after learning by using Constructionism to develop student's communication skills through a SHARE learning process

\begin{tabular}{c|c|c|c|c|c|c}
\hline Test & $\mathrm{n}$ & Mean & S.D. & X & S.D. & $\mathrm{t}$ \\
\hline Pre-test & 33 & 15.78 & 1.211 & 9.19 & 1.48 & $22.95^{*}$ \\
Post-test & 33 & 24.97 & 2.443 & & & \\
\hline
\end{tabular}

$\mathrm{t}) .05,31(=1.6955$

* statistically at the .05 level of significance .05

From table 3, The results of comparing the students' achievement before learning are 15.78 and after learning is 24.97. The results of comparing the students' achievement are after learning is higher than before learning statistically at the .05 level of significance.

Part 4: The results of study students' satisfaction towards English learning through a SHARE learning process between before learning and after learning.

Table 4: The results of study students' satisfaction

\begin{tabular}{l|c|c|c}
\hline Assessment item & $\mathbf{X}$ & S & Level satisfaction \\
\hline 1. The pattern is clear. & 4.70 & 0.47 & the most \\
2. The use of language that is easy to & 4.39 & 0.50 & a lot
\end{tabular}


understand

3. Have a good feeling in studying

4. The time specified for the activity is appropriate.

5. Students learn more quickly.

6. The answer to the skill exercises is clear. easy to understand

7. Students communicate better in English.

8. Students can communicate in English by themselves.

9. Students are confident in communicating in English.

10. Students can converse in English in daily life. total

\begin{tabular}{l|l|r}
4.48 & 0.51 & a lot \\
4.30 & 0.56 & a lot \\
3.96 & 0.21 & $\begin{array}{l}\text { a lot } \\
\text { the most }\end{array}$ \\
4.65 & 0.57 & a lot \\
4.22 & 0.42 & a lot \\
4.26 & 0.45 & a lot \\
4.13 & 0.55 & the most \\
4.61 & 0.50 & a lot
\end{tabular}

From table 4, The result is the students had satisfaction with learning by using Constructionism to develop student's communication skills through a SHARE learning process The students were satisfied with their learning at the highest level. There was a high level of satisfaction. $(X=4.37$, S.D. $=0.15)$

\section{Discussion and conclusion}

1. The results of the review of the effectiveness of using Constructionism to develop student's communication skills through a SHARE learning process lesson plans for Grade 8 students had an efficiency of $84.50 / 84.65$ higher than the set threshold of 75/75. The researcher looking for the quality of the instructional model can see that the teaching style is of the quality according to the specified criteria because the researcher has studied the design theory according to the lesson design and development principles. The body of knowledge based on constructivist theory is clear and appropriate from the assessment of the opinions of the experts as a whole at the appropriate level, in line with Tissana Khamanee. (2005) said that the teaching style is a condition. Nature of learning encompasses the essential elements that are organized in a manner based on a variety of philosophies, theories, principles, concepts, or beliefs, comprising key processes or steps in teaching and learning and teaching methods. Cobb, Wood and Yackel 1991, cited in Rassamee Suchin Brahma 68 teamed up with 18 teachers from the same school system to experimentally teach mathematics to grade 2 students aged 7 years with a constructivist teaching method. Autism for one academic year under school regulations, for example, the school group's math learning objectives must use averages from standardized achievement tests. A standardized achievement test is a criterion for evaluating learning and also faces the concerns of parents of students participating in the program, although these limitations influence constructivism. WIT 254380670681200067 Bigge 1976 studied constructivist teaching methods and found that it can help students to develop competence and understanding of thinking, curiosity, investigate perseverance and prudence 
2. The results of comparing the students' achievement before learning are 15.78 and after learning is 24.97. The results of comparing the students' achievement are after learning is higher than before learning statistically at the .05 level of significance. The researcher tested the students' knowledge. both before and after school by using the same academic achievement test and compare the test results In order to know the learning development of students, it was found that after the students developed English communication skills by using Constructionism to develop student's communication skills through a SHARE learning process. Students have higher academic achievement than before learning. which means Students have improved their communication skills in English. Field \& Gild (Field \& Gild. 1980: 67-73). Said that A study on the satisfaction of students towards the management of graduate studies in business schools to find the dimensions of satisfaction and dissatisfaction with educational programs and educational experiences in the Faculty of Higher Professions was found. The eight dimensions of satisfaction were satisfaction with social and work relationships as a friend, satisfaction with peers' cognitive stimuli, satisfaction between students and teachers, satisfaction with free choice of program. Satisfaction with the progress of the course in the curriculum and satisfaction with setting the rules that students should follow do.

3. The result is the students had satisfaction with learning by using Constructionism to develop student's communication skills through a SHARE learning process The students were satisfied with their learning at the highest level. There was a high level of satisfaction. ( $X=$ 4.37, S.D. $=0.15)$. After students learn English by using Constructionism to develop student's communication skills through a SHARE learning process. The researcher asked a b o u t the students' learning satisfaction. by using a questionnaire of 10 questions for students to choose answers and evaluate the score according to the level of satisfaction As a result, students were satisfied with their studies at the highest level. Wade (Wade 1995: 3411-A) examined the effect of constructivist learning solution mathematics teaching on learning achievement. The selfconfidence and attitudes towards mathematics of grade 5 students were studied by a sample of 17 students and a 6-week period taught 3 hours 30 minutes daily. The researcher used statistics!test. To compare the learning achievements and use qualitative research to study the attitudes and self-confidence in learning mathematics of the samples by means of observation and interview. The results showed that the sample's learning achievement increased significantly. With statistical significance at the level of less than 0.05, the researcher was able to test the results (2nd posttest) as well as (first posttest). Constructivist theory had a statistically significant increase in learning achievement higher than that of high-achieving students at a level of less than 0.05 . Self-confidence in the mathematics of the sample was higher.

\section{Acknowledgements}

On the success of this research, I would like to extend deep thanks to Loei Primary Educational Service Area Office 2. Thank you Mr. Surin Kaewbootdee, the director of Bannonsawan School to give good advice. Thank you Dr. Wanida Simpol, the research advisor for giving me suggestions, ideas, as well as guiding me to get through obstacles and difficulties in conducting research. I would like to thank Miss Aphiradee Sornnara and Mr. Natthawut Promtara for being a proof reader and thank you Miss Suwimol Mala and Mrs. Namaoy Botmart to give me a very good supporter.

\section{REFERENCES}


Ministry of Education. Basic Education Core Curriculum (2008). Bangkok: Agricultural Cooperative Association of Thailand Printing House, 2008.

Bannonsawan School.Report of quality assessment within educational institutions. Loei: Copy document, 2021

Boonchom Srisaat. (2002). Preliminary research. Print the 7th time. Bangkok: Suree Wiyasan Rattana Buason. (2011). Research and Development of Educational Innovations. Second printing. Nakhon Sawan: Rimping

Printing.

Sommai Kaewkanha. (2015). Development of inverted classroom cooperative learning activities

using ED media, LTV. Mahasarakham Rajabhat: Mahasarakham.

Sirikorn Bamrungkit, Santi Wichakkanalan, and Thoothong Kwangsawas. (2019). Teaching style English with blended

learning to promote communication skills. Research Journal Khon Kaen University

(Graduate edition) in the field of

humanities and social sciences. 7(2), 59-70.

Aps, J. (2006). Higher Education in a Learning Society. San Francisco: Jossey Bass.

Borg, Walter R. (1989). Education Research An Introduction. 5" ed., New York: Longman.

Bullock, Velma Lucille. (1996, August). The Influences of a Constructivist Teaching Approach on Students' Attitudes

toward Mathematics in a Preservice Elementary Teachers Mathematics Course.

Dissertation Abstracts

International. 57(2):

$611 \mathrm{~A}$.

Ellis, R. (2003). Task-based Language Learning and Teaching. Oxford, New York: Oxford Applied Linguistics.

Field, H.S. ;\& Gild., W. (1980). "Student Dimensionality And assessment in a school of business," Educational Research

Quarterly. 5 (Summer).

Kerr, J.A. "A Qualitative Description Analysis and Evaluation of An Eighth Grade Writing Workshop (Social Constructivism)." Dissertation Abstract International 58 (November 1997) : 2.

Khasen, J. (1985). Teacher as Researcher. London: Routledge Falmer.

Marchiori,I. The constructivism defined by pre school teachers [Online]. Accessed 23 April 2001. Available from

http://www.marvey.com.br/constructivism.html

Piaget, J. The Principle of Genetic Epistemology. London : Wolfe Mays, 1972. Taylor, F.W. The history management [Online].

Accessed 17 September 2001. Available from http://www.mgmtguru.com/mgt301/301Ipage8.htm

Tissana Khamanee(2005). Pedagogical Science. Bangkok : Chulalongkorn University.

Wade, Eileen Gray. A study of Effects of Constructivist-based Mathematics Problem Solving Instructional Program on the

Attitudes, Self-confidence, and Achievement of Post-fifth-grade Students (Thailand)

[CD-ROM] .1995. Abstract from File: Dissertation Abstracts Item: 3411-A.. 
UMGCINMATIC : $1^{\text {st }}$ Rethinking Education during Covid-19 Era: Challange and Innovation Volume 1 No 2

Zahorik, J. A. (1995). Constructivist Teaching. Fastback 390. Phi Delta Kappa, PO Box 789, Bloomington, IN 47402-0789.. 